\title{
STRATEGI PENGEMBANGAN PARIWISATA PESISIR DI DESA BENTUNG KABUPATEN KEPULAUAN SANGIHE PROVINSI SULAWESI UTARA
}

\section{Coastal Tourism Development Strategy in The Bentung Village, Sangihe Islands Regency of North Sulawesi}

\author{
*Aldy Adrianus Tatali, Ridwan Lasabuda, \\ Jardie A. Andaki dan Bet E. S. Lagarense \\ Fakultas Perikanan dan IImu Kelautan, Universitas Sam Ratulangi, Indonesia \\ Jl. Kampus Unsrat Bahu, Kleak, Manado. \\ Diterima tanggal: 22 Maret 2018 Diterima setelah perbaikan: 8 Mei 2018 \\ Disetujui terbit: 6 Juni 2018 \\ *email: aldy07tatali@gmail.com
}

\begin{abstract}
ABSTRAK
Pengelolaan pariwisata pesisir Kabupaten Kepulauan Sangihe telah banyak diteliti namun penelitian yang menekankan pada pengembangan potensi pariwisata pesisir desa bentung belum dilakukan. Kabupaten Kepulauan Sangihe merupakan kabupaten bahari yang memiliki Kawasan Strategis Pariwisata sesuai dengan PERDA Kepulauan Sangihe Nomor 15 Tahun 2008, yaitu kawasan yang memiliki fungsi utama pariwisata atau memiliki potensi untuk pengembangan pariwisata yang mempunyai pengaruh penting dalam satu atau lebih aspek seperti pertumbuhan ekonomi, sosial dan budaya, pemberdayaan sumber daya alam, daya dukung lingkungan hidup, serta pertahanan dan keamanan Desa Bentung mempuyai atraksi wisata Mairokang Beach Game (MBG) yang diselenggarakan setiap tahun. Penelitian ini berfokus pada pengembangan atraksi wisata pesisir di Desa Bentung dengan bentuk diversifikasi produk-produk wisata yang masih banyak selain lomba MBG. Penelitian dilakukan pada bulan Oktober 2016 hingga Maret 2017 mengunakan metode observasi, kualitatif dan kualitatif (campuran). Metoda analisis deskriptif dan SWOT digunakan dalam penelitian ini. Hasil penelitian mmenunjukkan bahwa potensi sumber daya pesisir di Desa Bentung seperti terumbu karang, hutan mangrove yang memiliki luas 2,82 Ha, keadaan hutan Mangrove tergolong dalam kondisi tidak rusak. Potensi pariwisata pantai Desa Bentung memiliki tiga kawasan pantai yang memiliki pasir yang berbeda yaitu Pantai Bulo, Pantai Nagha, Pantai Mairokang Bentung. MBG melaksanakan kegiatan - kegiatan yang bernuansa budaya Sangihe dan menjadi daya tarik wisata Kabupaten Kepulauan Sangihe, lomba ini merupakan lomba balap perahu. Hasil penelitian menyarankan perlunya fokus pembangunan sarana dan prasarana pariwisata.
\end{abstract}

Kata Kunci: strategi pengembangan pariwisata; pesisir; Desa Bentung; Mairokang Beach Game

\begin{abstract}
Management of Sangihe coastal tourism has been extensively researched; however, research emphasizing on the development of coastal tourism potentials in Bentung Villages has yet been carried out. The regency of Kepulauan Sangihe which is a maritime regency has a Tourism Strategic Area in Sangihe Islands Local Regulation No. 15 Year 2008 which tell that a region that has a major function of tourism or has potential for tourism development that has an important influence in one or more aspects such as economic, social and cultural growth, natural resources empowerment, environmental carrying capacity, defense and security. Bentung Village a tourist attraction such as Mairokang Beach Game (MBG) that held annually. This study focuses on the development of coastal tourism attractions in the village of Bentung with a diversified form of tourism products that are still many other than the MBG competition. This research was conducted between October 2016 until March 2017 using qualtitaive and quantitative observation method (mix method). A descriptive and SWOT analysis were used in this study. Results of the research showed that potential of coastal resources in Bentung Village such as coral reefs, mangrove forest has an area of $2.82 \mathrm{Ha}$ and classified as undamaged. Bentung Beach tourism has three areas that have different sand such as Bulo Beach, Nagha Beach and Mairokang Beach. MBG carries out cultural activities of Sangihe and becomes a tourist attraction of Kepulauan Sangihe Regency, This attraction is a boat racing competition. The research suggests the need to be focused on the development of tourism's infrastructure and facilities.
\end{abstract}

Keywords: tourism development strategy; coastal; Bentung Village; Mairokang Beach Game 


\section{PENDAHULUAN}

Penelitian ini bertujuan untuk menemukan potensi pariwisata pesisir yang di Kabupaten Kepulauan Sangihe yang memiliki potensi pariwisata pesisir yang besar, tapi belum dikelola dengan maksimal, maka dalam rangka meningkatkan sektor pariwisata di Kabupaten Kepulauan Sangihe diperlukan kajian lebih spesifik tentang strategi perkembangan karakteristik dan potensi pariwisata pesisir khususnya di Desa Bentung Kecamatan Tabukan Selatan, mengingat sebagian besar objek wisata di kawasan ini belum dikembangkan. Kajian ini diharapkan selain untuk memperkenalkan dan mengembangkan objek wisata yang ada, juga untuk meningkatkan kunjungan wisatawan serta meningkatkan Pendapatan Asli Daerah Kabupaten Kepulauan Sangihe disektor pariwisata bahari. Salah satu desa di Kabupaten Kepualauan Sangihe mempunyai potensi dalam pariwisata pesisir yaitu Desa Bentung di Kecamatan Tabukan Selatan. Desa Bentung mempuyai atraksi wisata yang diselenggarakan setiap tahun yaitu lomba balap perahu yaitu Mairokang Beach Game (MBG) yang sudah dua kali dilaksanakan. Penelitian ini berfokus pada pengembangan atraksi wisata pesisir di Desa Bentung dengan bentuk diversifikasi produk-produk wisata yang masih banyak selain lomba MBG.

Pariwisata (tourism) atau kepariwisataan adalah keseluruhan kegiatan yang terkait dengan pariwisata dan bersifat multidimensi serta multidisiplin yang muncul sebagai wujud kebutuhan setiap orang dan negara serta interaksi antara wisatawan dan masyarakat setempat, sesama wisatawan, Pemerintah, Pemerintah Daerah, dan pengusaha (UU 10/2009). Pengertian pariwisata adalah suatu perjalanan yang dilakukan untuk sementara waktu, yang diselenggarakan dari suatu tempat lain, dengan maksud bukan untuk berusaha (business) atau mencari nafkah di tempat lain yang dikunjungi, tetapi semata-mata untuk menikmati perjalanan tersebut guna pertamasyaan dan rekreasi atau untuk memenuhi keinginan yang beraneka ragam (Yoeti, 1996). Pariwisata atau tourism memiliki ruang lingkup dan kegiatan yang luas, setidaknya meliputi lima jenis kegiatan meliputi wisata bahari (beach and sun tourism), wisata pedesaan (rural and agro tourism), wisata alam (natural tourism), wisata budaya (cultural tourism), atau perjalanan bisnis (business travel). Posisi pariwisata pesisir (ecotourism) memang agak unik, berpijak pada tiga kaki sekaligus, yakni wisata pedesaan, wisata alam dan wisata budaya (Nugroho, 2006).
Menurut Dahuri et al. (2001) Kegiatan pariwisata memiliki banyak jenis baik pariwisata buatan dan pariwisata alam, dalam pariwisata alam ada beberapa bentuk kegiatan pariwisata, salah satu kegiatan pariwisata alam tersebut adalah kegiatan pariwisata pesisir, Kegiatan wisata pesisir adalah kegiatan rekreasi yang dilakukan sekitar pantai seperti berenang, berselancar, berjemur, menyelam, snorkeling, berjalan-jalan atau berlarilari di sepanjang pantai, menikmati keindahan suasana pesisir, dan bermeditasi.

Pokok masalah dalam penelitan ini ialah: Strategi pengembangan atraksi wisata di kawasan pesisir di Desa Bentung. Pokok masalah ini dapat disusun secara rinci dalam rumusan sebagai berikut:

(1) Bagaimana potensi pariwisata di Desa Bentung?

(2) Bagaimana atraksi wisata pesisir yang ada di Desa Bentung?

(3) Apa dan bagaimana strategi pengembangan dan pengelolaan kawasan pariwisata pesisir di Desa Bentung?

Tujuan penelitian ini merupakan tindak lanjut dari masalah yang telah dirumuskan. Dengan kata lain tujuan yang ingin dicapai dalam penelitian ini adalah untuk:

(1) Mengidentifikasikan potensi sumberdaya pesisir untuk pengembangan pariwisata pesisir di Desa Bentung.

(2) Mendeskripsikan atraksi wisata pesisir Mairokang Beach Game di perairan desa bentung Kecamatan Tabukan Selatan Kabupaten Kepulauan Sangihe.

(3) Menyusun strategi pengembangan wisata pesisir di Desa Bentung sesuai dengan potensi sumberdaya yang ada.

\section{METODOLOGI}

Metode yang digunakan dalam penelitian ini adalah metode penelitian campuran (mixedmethod). Metode ini dipilih karena penelitian ini menggabungkan hasil dari dua metode penilaian yaitu metode kualitatif dan kuantitatif. Adapun input data yang digunakan dalam metode kualitatif antara lain kesesuaian kawasan pantai dan peran serta pemerintah. Data luasan terumbu karang dan kepadatan hutan Mangrove menjadi input data dalam metode kuantitafif (Creswell, 2010). 


\section{Metode Pengumpulan Data}

Metode pengumpulan data didapat dari studi lapangan dan studi pustaka, pengamatan langsung dan wawancara. Adapun jumlah responden yang menjadi narasumber wawancara adalah 3 orang dengan rincian 2 orang dari Dinas Kebudayaan (Kepala Dinas dan Sekretaris) dan 1 orang dari BAPPEDA Kabupaten Kepulauan Sangihe (Sekretaris).

\section{Metode Pengamatan Terumbu Karang}

Pengamatan terumbu karang dilakukan dalam penelitian ini untuk mengetahui kondisi terumbu karang beserta luas terumbu karang pada lokasi penelitian, yaitu dengan cara pengamatan Snorkling dan Manta Tow, yaitu pengamatan dengan mengunakan perahu dan papan manta yang berfungsi sebagai tempat pengikat tali dari perahu ke pengamat.

$$
\% \text { Coverage }=\frac{\begin{array}{c}
\text { Panjang Penutupan } \\
\text { Jenis Spesies }-i \\
\text { Species }- \text { i coverage } \\
\text { area length) }
\end{array}}{\text { Total Panjang }} \times 100 \%
$$

\section{Metode Analisis Hutan Mangrove}

Pengamatan kondisi hutan Mangrove di desa bentung mengunakan peneltian Transek dalam penelitian ini digunakan dua pengamatan dan dalam setiap pengamatan mengunakan dua kuadran dapat dilihat pada Tabel 1.

\section{Metode Analisis Kesesuaian Kawasan Pantai}

Analisis kesesuaian yang dilakukan dalam penelitian ini hanya difokuskan untuk peruntukan kawasan ekowisata bahari (jenis kegiatan selam, snorkeling dan wisata pantai). Pemberian bobot berdasarkan tingkat kepentingan suatu parameter, sedangkan pemberian skor berdasarkan kualitas setiap parameter.

\section{Metode Analisis SWOT}

Strategi pengembangan mengunakan metode analisis SWOT dengan melihat kekuatan, kelemahan dan ancaman yang ada dalam pengembangan pariwisata pesisir di Desa Bentung.

\section{HASIL DAN PEMBAHASAN}

\section{Potensi Sumberdaya Pesisir}

Sumber daya pesisir dapat dibedakan dari sumberdaya perairan pesisir dan daratan pesisir. Sumber daya perairan pesisir meliputi semua yang ada di wilayah perairan, misalnya sumber daya ikan, terumbu karang, Mangrove, atau kandungan mineral di dasar perairan. Sedangkan sumber daya daratan pesisir meliputi semua yang ada di wilayah daratan yang masih termasuk kawasan pesisir, seperti hutan, perkebunan, atau bahkan perairan tawar (Bengen, 2001).

\section{Terumbu Karang}

Terumbu karang merupakan salah satu daya tarik di kawasan pesisir bagi para pencinta snorkeling dan diving. Kawasan terumbu karang desa Bentung terbagi menjadi dua stasiun yang pertama berada di pingiran pantai Desa Bentung yang kedua dikawasan karang timbul atau Terumbu Karang Maritekang. Pengambilan penelitian dalam luasan terumbu karang di kedua stasiun itu mengunakan metode penelitian Manta Tow, data luasan terumbu karang ini dapat dilihat pada Tabel 2 dan Tabel 3.

Peningkatan pariwisata diharapkan akan jadi semakin membaik dengan kegiatan pemanfaatan pariwisata pesisir misalnya lomba Mairokang Beach Game di Desa Bentung. Pada lokasi di stasiun I diperlukan rehabilitasi terumbu karang di wilayah ini, karena perusakan di wilayah ini sudah besar selain rehabilitasi diperlukan konservasi kawasan terumbu karang di wilayah ini.

Tabel 1. Parameter Hutan Mangrove.

Table 1. Mangrove Forest Parameter.

\begin{tabular}{ccc}
\hline Parameter & Kriteria Kerusakan/ Damage citeria & Nilai/Value \\
\hline Jumlah Pohon/ & Berat/Heavy & $N<1000$ pohon (tress)/ ha \\
Number of trees $(N)$ & Sedang/Intermediate & $N=1500-1000$ pohon (tress)/ ha \\
& Tidak rusak/ Not damage & $N>1500 /$ ha \\
\hline
\end{tabular}


Tabel 2. Tutupan Karang Pada Station I.

Table 2. Coral Coverage in Station I.

\begin{tabular}{clccc}
\hline No & $\begin{array}{c}\text { Jenis Karang Hidup/ } \\
\text { Type of Coral Life }\end{array}$ & $\begin{array}{c}\text { Tutupan Karang/l } \\
\text { Coral Cover (\%) }\end{array}$ & $\begin{array}{c}\text { Jenis Karang Mati/Type } \\
\text { of Coral Dead }\end{array}$ & $\begin{array}{c}\text { Tutupan Karang/ } \\
\text { Coral Cover (\%) }\end{array}$ \\
\hline 1 & Coral Submassive & 6.31 & Dead Coral Algea & 15.32 \\
2 & Acropora Branching & 9.57 & Dead Coral & 37.13 \\
3 & Acropora Tabulate & 8.22 & & \\
4 & Zoanthids & 2.11 & & \\
5 & Ascidians & 1.32 & & \\
6 & Coral Millepora & 2.31 & & \\
7 & Aeopora Digitate & 2.45 & & \\
8 & Coralas Massive & 5.24 & & \\
9 & Coral Mushoorm & 5.78 & & $\mathbf{5 2 . 4 5}$ \\
\hline
\end{tabular}

Tabel 3. Tutupan Karang Pada Station II.

Table 3. Coral Coverage in Station II.

\begin{tabular}{clccc}
\hline No & $\begin{array}{c}\text { Jenis Karang Hidup/ } \\
\text { Type of Coral Life }\end{array}$ & $\begin{array}{c}\text { Tutupan Karang/l } \\
\text { Coral Cover (\%) }\end{array}$ & $\begin{array}{c}\text { Jenis Karang Mati/Type } \\
\text { of Coral Dead }\end{array}$ & $\begin{array}{c}\text { Tutupan Karang/ } \\
\text { Coral Cover (\%) }\end{array}$ \\
\hline 1 & Coral Submassive & 10.53 & Dead Coral Algea & 13.32 \\
2 & Acropora Branching & 12.88 & Dead Coral & 18.27 \\
3 & Acropora Tabulate & 11.04 & & \\
4 & Zoanthids & 4.31 & & \\
5 & Ascidians & 1.15 & & \\
6 & Coral Millepora & 2.45 & & \\
7 & Aeopora Digitate & 4.08 & & \\
8 & Coralas Massive & 5.35 & & \\
9 & Coral Mushoorm & 8.27 & & 31.59 \\
\hline
\end{tabular}

Hasil penelitian di atas mengunakan metode penelitian observasi lapangan dengan Kondisi tutupan karang pada stasiun II yang merupakan karang timbul (maritekang), rata-rata tutupan karang $60,06 \%$ dengan kondisi tutupan karang baik, dan kondisi kerusakan terumbu karang yaitu $31,59 \%$. Kondisi ini lebih baik dibandingkan dengan kondisi tutupan karang pada stasion I.

Kondisi terumbu karang yang baik pada stasion II menjadi tempat yang baik untuk kegitana pariwisata pesisir seperti snorkeling dan diving, tapi masih perlu peningkatan sarana prasarana dalam mengembangkan kawasan ini menjadi objek pariwisata.

\section{Hutan Mangrove}

Hutan Mangrove atau yang sering disebut warga sebagai bentung pahepa ini memiliki potensi dalam pengembangan pariwisata, luas hutan Mangrove Desa Bentung sebesar 2,82 $\mathrm{Ha}$
Desa Bentung memiliki beberapa jenis tumbuhan Mangrove (Aegiceras corniculatum, Sonneratia alba, Rhizophora apiculata, Rhizophora mucronata).

Hasil penelitian kawasan hutan Mangrove dengan mengunakan metode transek didapatkan hasil penelitian pada dua pengamatan, bahwa kondisi hutan Mangorve di Desa Bentung tergolong pada kondisi tidak rusak.

\section{Pantai}

Wisata pesisir tidak jauh dari wisata pantai dimana para wisatawan melakukan aktivitas mandi dan berjemur serta main pasir dan melakukan kegiatan olahraga di daerah pantai. Lokasi-lokasi pantai mencakup: (1) Pantai Bulo memiliki pasir putih dengan kondisi pantai indah dan panjang; (2) Pantai Nagha pasir dua warna yang menurut warga awalnya hitam tapi sekarang sudah bercampur dengan pasir putih, ini karena karang mati yang terjadi hingga munculnya pasir-pasir putih di pantai 
tersebut, dan; (3) Pantai Mairokang atau pantai Desa Bentung yang merupakan lokasi kegiatan lomba mairokang dan satu-satunya pantai yang dihuni masyarakat.

\section{Atraksi Wisata Mairokang Beach Game}

Sesuai dengan implementasi visi Daerah Kabupaten Kepulauan Sangihe sebagai Kabupaten Bahari yang sejahtera dan bermartabat serta meningkatkan potensi bahari di Kabupaten Kepulauan Sangihe khususnya di Kecamatan Tabukan Selatan, maka "Mairokang Beach Game" (MBG) Kampung Bentung melaksanakan kegiatan-kegiatan yang bernuansa budaya Sangihe. Kegiatan Lomba MBG baru berlangsung yang kedua kalinya di tahun 2016, kegiatan lomba MBG pertama di mulai pada Tahun 2015 dan akan dilaksanakan di tiap tahunnya dan rencananya untuk tahun 2017 akan di selengarakan di Bulan September, dan kegiatan ini akan terus di selengarakan pada pantai Desa Bentung (Mairokang).

Kegiatan atraksi wisata Mairokang Beach Game baru saja dimasukkan dalam kalender wisata di Kabupaten Sangihe. Kegiatan ini memiliki kelebihan jika dibandingkan dengan lomba yang sudah masuk dalam kalender pariwisata nasional seperti lomba Manggurebe Arumbae yang hanya terdiri dari dua kegiatan lomba balap perahu (Kertopati, 2016) :

(1) Lomba perahu tradisional atau Manggurebe Arumbae adalah lomba balapan mendayung perahu hingga batas terakhir. Satu perahu terdiri dari 28-31 peserta lelaki, dan;

(2) Lomba perahu semang (bercadik), yakni lomba balapan perahu di laut yang didayung oleh perempuan yang memakai pakaian tradisional Maluku.

Kegiatan Mairokang Beach Game berkembang dari tahun ke tahun. Terjadi pertumbuhan peserta di tahun 2015 jumlah peserta 52 peserta dan jumlah peserta bertambah hingga 79 peserta pada tahun 2016 .

\section{6. trategi Pengembangan Wisata Pesisir Desa Bentung}

Pengembangan pariwisata diperlukan perencanaannya tidak hanya mementingkan wisatawan, tetapi harus melibatkan semua pihak yaitu para stakeholder, pemerintah, dan kalangan masyarakat umum (lokal). Sehingga diperlukannya kesepahaman mengenai seluk beluk kepariwisataan, dampak positif dan negatifnya dan juga timbal balik antara sektor pariwisata dengan sektor lainnya.

Menurut Nawawi (2005:147) secara etimologis (asal kata) penggunaan kata strategi dalam manajemen sebuah organisasi diartikan sebagai kiat, cara, dan taktik utama yang dirancang secara sistematik dalam melaksanakan fungsifungsi manajemen, yang terarah pada tujuan organisasi. Berbicara tentang strategi tidak dapat dipisahkan dari pengertian manajemen strategik. Menurut Siagian (2011:15) manajemen strategik adalah serangkaian keputusan dan tindakan mendasar yang dibuat oleh manajemen puncak dan diimplementasikan oleh jajaran suatu organisasi dalam rangka pencapaian tujuan organisasitersebut. Menurut David (2009:5) manajemen strategik dapat didefinisikan sebagai seni dan pengetahuan dalam merumuskan, mengimplementasikan, serta mengevaluasi keputusan-keputusan lintas fungsional yang memampukan sebuah organisasi mencapai tujuannya. Lebih lanjut dijelaskan bahwa dalam proses manajemen strategi terdiri atas tiga tahap, yaitu: (a) perumusan strategi; (b) penerapan strategi, dan; (c) penilaian strategi. Menurut Soebagyo, 2012 pengembangan pariwisata yang menunjang pertumbuhan ekonomi dapat dilakukan dengan memperhatikan beberapa hal sebagai berikut:

(1) Perlu ditetapkan beberapa peraturan yang berpihak pada peningkatan mutu pelayanan pariwisata dan kelestarian lingkungan wisata, bukan berpihak pada kepentingan pihak-pihak tertentu. Selain itu perlu diambil tindakan yang tegas bagi pihak-pihak yang melakukan pelanggaran terhadap aturan yang telah ditetapkan;

(2) Pengelola pariwisata harus melibatkan masyarakat setempat. Hal ini penting karena pengalaman pada beberapa Daerah Tujuan Wisata (DTW), sama sekali tidak melibatkan masyarakat setempat, akibatnya tidak ada sumbangsih ekonomi yang di peroleh masyarakatsekitar. Contoh kasus: pengelolaan DTW di Pantai Wanukaka, Kabupaten Sumba Barat, NTT. Pada DTW tersebut masyarakat tidak berkesempatan untuk terlibat, baik untuk menjual hasil-hasil pertanian, kerajinan maupun menjadi karyawan di tempat itu; 
(3) Kegiatan promosi yang dilakukan harus beragam, selain dengan mencanangkan cara kampanye dan program Visit Indonesian Year seperti yang sudah dilakukan sebelumnya, kegiatan promosi juga perlu dilakukan dengan membentuk sistem informasi yang handal dan membangun kerjasama yang baik dengan pusat-pusat informasi pariwisata pada negara-negara lain, terutama negara-negara yang potensial;

(4) Perlu menentukan DTW- DTW utama yang memiliki keunikan dibanding dengan DTW lain, terutama yang bersifat tradisional dan alami. Kebetulan saat ini obyek wisata yang alami dan tradisional menjadi sasaran utama para wisatawan asing. Obyek ini sangat banyak ditemukan di luar Jawa, misalnya di daerahdaerah pedalaman Kalimantan, Papua dan lain-lain;

(5) Pemerintah pusat membangun kerjasama dengan kalangan swasta dan pemerintah daerah setempat, dengan sistem yang jujur, terbuka dan adil. Kerja sama ini penting untuk lancarnya pengelolaan secara profesional dengan mutu pelayanan yang memadai. Selain itu kerjasama di antara penyelenggara juga perlu dibangun. Kerjasama di antara agen biro perjalanan, penyelenggara tempat wisata, pengusaha jasa akomodasi dan komponenkomponen terkait lainya merupakan hal yang sangatpenting bagi keamanan kelancaran dan kesuksesan pariwisata;

(6) Perlu dilakukan pemerataan arus wisatawan bagi semua DTW yang ada di Seluruh Indonesia. Dalam hal ini pemerintah juga harus memberikan perhatian yang sama kepada semua DTW, perhatian DTW yang sudah mandiri hendaknya dikurangi dan memberikan perhatian yang lebih terhadap DTW yang memerlukan perhatian lebih;

(7) Mengajak masyarakat sekitar DTW agar menyadari peran, fungsi dan manfaat pariwisata serta merangsang mereka untuk memanfaatkan peluang-peluang yang tercipta bagi berbagai kegiatan yang dapat menguntungkan secara ekonomi. Masyarakat diberikan kesempatan untuk memasarkan produk-produk lokal serta membantu mereka untuk meningkatkan keterampilan dan pengadaan modal bagi usaha-usaha yang mendatangkan keuntungan;
(8) Sarana dan prasarana yang dibutuhkan perlu dipersiapkan secara baik untuk menunjang kelancaran pariwisata. Pengadaan dan perbaikan jalan, telepon, angkutan, pusat perbelanjaan wisata dan fasilitas lain di sekitar lokasi DTW sangat diperlukan.

Ketika melakukan perjalanan, pasti terdapat daerah yang dituju. Daerah inilah yang disebut Daerah Tujuan Wisata. Sesuai dengan Undangundang Republik Indonesia Nomor 10 Tahun 2009 Tentang Kepariwisataan, Daerah Tujuan Wisata yang selanjutnya disebut Destinasi Pariwisata adalah kawasan geografis yang berada dalam satu atau lebih wilayah administrasi yang didalamnya terdapat daya tarik wisata, fasilitas umum, fasilitas pariwisata, aksesibilitas, serta masyarakat yang saling terkait dan melengkapi terwujudnya kepariwisataan. Destinasi pariwisata harus memenuhi tiga syarat (Yoeti, 1996), yaitu:

(1) Harus memiliki something to see, yaitu di tempat tersebut harus ada obyek dan atraksi wisata khusus, yang berbeda dengan apa yang dimiliki daerah lain untuk dilihat;

(2) Harus menyediakan something to do, yaitu di tempat tersebut harus tersedia fasilitas untuk melakukan kegiatan reaksi yang dapat membuat betah wisatawan, dan;

(3) Harus menyediakan something to buy, yaitu di tempat tersebut harus tersedia fasilitas untuk belanja, terutama oleh-oleh dan barang kerajinan khas yang dapat dibawa pulang ketempat asal oleh wisatawan.

Daya tarik wisata adalah segalah sesuatu yang memiliki keunikan, keindahan dan nilai yang berupa keanekaragaman kekayaan alam, budaya, dan hasil buatan manusia yang menjadi sasaran atau tujuan kunjungan wisatawan. Berhasilnya suatu tempat berkembang menjadi Daerah Tujuan Wisata (DTW) sangat tergantung pada tiga faktor utama (Samsuridjal \& Kaelany, 1997).

(1) Atraksi:

a. Atraksi Tempat : umpamanya tempat dengan iklim yang baik, pemandangan yang indah atau tempat-tempat bersejarah

b. Atraksi Kejadian/ Pariwisata : Kongres, pameran atau peristiwa peristiwa olah raga, festival dan sebagainya. 
(2) Mudah dicapai (Aksesibilitas) :

Tempat tersebut dekat jaraknya, atau tersedia transportasi ke tempat itu secara teratur, sering, mudah, nyaman, dan aman.

(3) Amenitas:

Tersedianya fasilitas-fasilitas seperti tempat penginapan, restoran, hiburan, transportasi, lokal yang memungkinkan wisatawan berpergian ke tempat itu serta alat-alat komunikasi lainnya.

Proses perencanaan menggambarkan lingkungan yang meliputi elemen-elemen: politik, fisik, sosial, budaya dan ekonomi, sebagai komponen yang saling berhubungan dan saling tergantung, yang memerlukan berbagai pertimbangan (Paturusi, 2001). Pengembangan potensi pariwisata di Desa Bentung memerlukan pengembangan dalam sektor wisata alam yang mencakup penambahan sarana dan prasarana pariwisata dalam rangka menarik minat wisatawan. Dukungan masyarakat, pemerintah daerah dan swasta di perlukan dalam pengelolaan dan pengembagan pariwisata di Desa Bentung. Perencanaan pengembangan wisata pesisir tersaji dalam bentuk kawasan wisata yang ditampilkan pada Gambar 1.

Pengembangan pariwisata Desa Bentung memanfaatkan potensi sumber daya alam yang ada di Lokasi Penelitian, karena termasuk dalam desa pesisir sehingga dimanfaatkan potensi pariwisata yang ada di kawasan peisisr. Terdapat empat kawasan pesisir yang akan dimanfaatkan dalam pengembangan kawasan pariwisata Desa
Bentung seperti di tandai dengan tanda Titik-titik berbeda warna yang tampak dalam Gambar 1:

(1) Pantai Bulo: pantai dengan tanda warna putih, pantai tersebut pada lokasi-lokasi tertentu memiliki gelombang yang cukup lumayan dapat setinggi 2-3 meter, sehingga lokasi tersebut dapat dimanfaatkan sebagai wisata selancar dan kegiatan wisata pantai lainnya.

(2) Pantai Nagha: lokasi yang ditandai dengan tanda warna merah, pantai tersebut keadaan perairannya lebih tenang, sehingga dapat dimanfaatkan untuk kegiatan jet ski dan banana boat, dan pemanfaatan kegiatan pesisir lainnya.

(3) Kawasan karang Timbul (Maritekang): lokasi yang ditandai dengan tanda warna kuning, kawasan ini memiliki potensi pariwisata dalam terumu karang sehingga kegiatan yang dapat dilakukan adalah snorkeling.

(4) Kawasan Hutan Mangrove Desa Bentung: lokasi yang ditandai dengan warna hijau, pemanfaatan kegiatan wisata di kawasan ini berbeda dengan kawasan wisata Mangrove yang lain kegiatan wisata hutan Mangrove di Desa Bentung dengan mengunakan kayak dalam menyusuri kawasan wisata hutan Mangrove.

Pengembangan kawasan wisata di Desa Bentung memerlukan dukungan dari semua pihak khususnya dukungan pemerintah daerah dalam persetujuan rencana dan bantuan dalam pengembangan kawasan wisata.

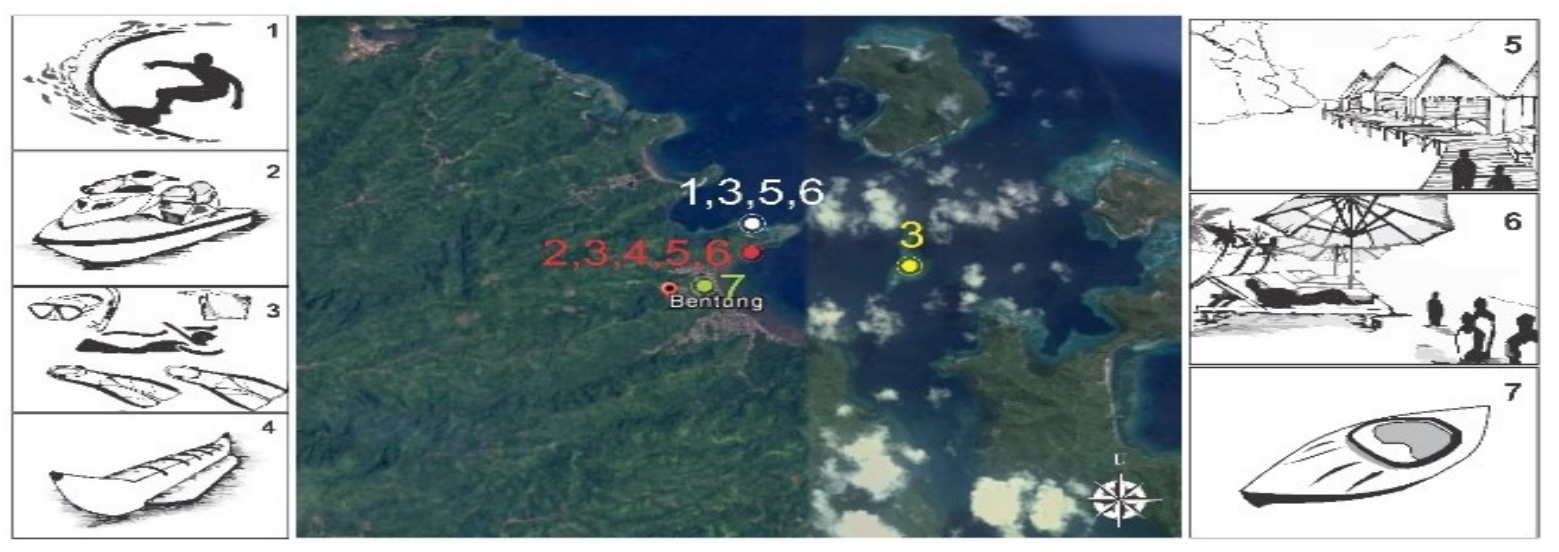

Gambar 8. Rencana Kawasan Wisata Pesisir Desa Bentung. Figure 8. Bentung Coastal Tourism Area Plan.

Sumber: Google Earth dan ArcGIS 10.3/Source: Google Earth and ArcGIS 10.3 


\section{Dukungan Pemerintah}

Konsep pariwisata pesisir berkelanjutan (sustainable coastal tourism) adalah pariwisata yang dapat memenuhi kebutuhan wisatawan maupun daerah tujuan wisata pada masa kini, sekaligus melindungi dan mendorong kesempatan serupa dimasa yang akan datang. Pariwisata berkelanjutan mengarah pada pengelolaan seluruh sumberdaya sedemikian rupa sehingga kebutuhan ekonomi, sosial, estetika dapat terpenuhi sekaligus memelihara integritas kultural, proses ekologi esensial keanekaragaman hayati dan sistem pendukung kehidupan (WTO, 1980).

Menurut UU No. 32 Tahun 2004. memberikan wewenang pengelolaan sumberdaya wilayah pesisir kepada pemerintahan provinsi, kota dan kabupaten. Provinsi diberi wewenang mengelola sejauh 12 mil mil laut, sementara kota serta kabupaten diberi wewenang 1/3 dari wilayah provinsi. Daerah-daerah yang memiliki wilayah pesisir dapat menggali potensi sebagai salah satu sentra produksi baru dalam mendorong pembangunan.

Masyhudzulhak (2011) menyatakan bahwa perspektif otonomi daerah dapat menjadi guideline dalam pengelolaan sumberdaya pesisir dengan tujuan (i) secara ekologis haruslah dapat menjamin kelestarian sumber daya pesisir, (ii) secara ekonomi dapat mendorong dan meningkatkan taraf hidup masyarakat serta meningkatkan pertumbuhan ekonomi daerah dengan tetap mempertahankan stabilitas produktivitas sumberdaya pesisir, (iii) secara sosial budaya memberikan ruang bagi kearifan lokal dan pemberdayaan masyarakat serta meningkatkan keterlibatan partisipasi masyarakat dalam kebijakan dan pembangunan, (iv) secara kelembagaan dan hukum dapat menjadi payung dalam pengelolaan sumberdaya pesisir dan menjamin tegaknya hukum serta penguatan kelembagaan, (v) dalam bidang pertahanan dan keamanan sebagai garda terdepan dalam mewaspadai potensi-potensi yang akan mengganggu kepertahanan dan kemanan baik di perairan maupun Zona Ekonomi Eksklusif, terutama dalam menjaga sumber daya pesisir dan kelautan.

Dukungan pemerintah dalam pengembangan pariwisata Sangihe sendiri sudah semakin membaik karena sudah langsung bekerja sama dengan kementrian pariwisata nasional telah di lakukan kegiatan pesona sangihe dalam memperkenalkan kabupaten sangihe di kanca nasional dan internasional.

\begin{abstract}
Promosi pariwisata dilakukan dengan melaunching pariwisata Sangihe di kementrian pariwisata dengan melakukan kegiatan kalender even festival pesona Sangihe ini dilakukan agar pemerintah pusat mengintervensi kegitan kalender even dan kebijakan dalam pengembangan pariwsata di Kabupaten Kepulauan Sangihe. (Wawancara, Sekretaris DIPARBUD Kab. Kep. Sangihe, 30-01-2017).
\end{abstract}

Desa Bentung sendiri memiliki banyak potensi yang belum di lirik dinas pariwisata dalam pengembangan pariwisata di Kabupaten Kepulauan Sangihe seperti pantai, terumbu karang, Mangrove dan wista-wisata yang lain, dalam dinas pariwisata pada Kecamatan Tabukan Selatan untuk wisata pendukung ada Teluk Manalu yang terletak di Desa Hangke dan Binebas berupa wisata pantai yang berpotensi pengembangan wisata water sport.

Pengembangan pariwisata di Desa Bentung selain kegiatan MBG didukung oleh seluruh masyarakat karena menurut masyarakat Desa Bentung memiliki potensi pariwisata pesisir, diharapkan ada partisipasi masyarakat dalam pengembangan pariwisata untuk memajukan wisata di Desa Bentung. Peningkatan partisipasi masyarakat dalam pengembangan pariwisata pesisir perlu ditingkatkan, seperti perlindungan lingkungan pada hutan Mangrove dan kawasan terumbu karang, dari tahun ke tahun sudah semakin baik dan sadar masyarakat dengan dampak keuntungan dari hutan Mangrove dan terumbu karang. Partisipasi merupakan salah satu faktor penting yang mendukung berkembangnya wisata pesisir sepertiyang ada di Kelurahan Muarareja, Kota Tegal dimana persentase partisipasi masyarakat mencapai $54 \%$ dan kelompok sadar wisata telah terbentuk (Muttaqin et al., 2015). Berbagai upaya untuk menjaga kelestarian lingkungan tidak akan efektif jika tidak didukung oleh masyarakat luas, khususnya penduduk setempat. Hal ini akan bermuara pada manfaat yang diperoleh penduduk setempat berupa pningkatan kesejahtraan hidup (Suwantoro, 2004)

\section{KESIMPULAN DAN IMPLIKASI KEBIJAKAN}

\section{Kesimpulan}

Berdasarkan hasil pembahasan dari penelitian ini maka dapat disimpulkan bahwa desa Bentung berpotensi sangat baik pada pariwisata 
pesisir ini dapat di lihat dari 4 kawasan pesisir yang dapat dimanfaatkan sebagai kawasan wisata di Desa Bentung seperti; Kawasan Terumbu Karang yang memiliki luas $0,391 \mathrm{Km}^{2}$, Kawasan Mangrove dengan luas 2,82 Ha dengan memiliki 4 jenis Mangrove yang hidup di Kawasan Hutan Mangrove Desa Bentung, Kawasan Pantai Bulo, dan Kawasana Pantai Nagha. Lomba Mairokang Beach Game merupakan lomba balap perahu satu-satunya di Kabupaten Kepulauan Sangihe dan kegiatan ini mendapat dukungan langsung oleh pemerintah Kabupaten Kepulauan Sangihe dan dukungan masyarakat pesisir Kabupaten Kepulauan Sangihe, untuk menunjukkan jati diri sebagai masayarakat bahari. Strategi pengembangan pariwisata pesisir di Desa Bentung dengan pembuatan peta rencana pengembangan wisata pesisir serta menggunakan analisis SWOT, dan empat pilar strategi pengembangan pariwisata Nasional, 1. Destinasi Pariwisata, 2. Industri Pariwisata, 3. Pemasaran Pariwisata, 4. Kelembagaan Pariwisata.

\section{Implikasi Kebijakan}

Penelitian ini diharapkan jadi bahan pertimbangan dagi pemerintah daerah Kab. Kep. Sangihe dalam pengembangan pariwisata pesisir, diperlukan koordinasi dan keterlibatan setiap stekholder dalam pengembangan Pariwisata pesisir khusunya dalam menyiapkan sarana dan prasarana pendukung kawasan pariwisata pesisir seperti infrastruktur pariwisata berupa penginapan serta kesiapan bandara dari kota-kota besar dan dibuat ruang zonasi daerah perlindungan ruang pesisir dan laut pengunaan lahan, agar tidak jadi tumpang tindih pemanfaatan.

\section{UCAPAN TERIMA KASIH}

Penulis mengucapkan terima kasih kepada Pemerintah dan Masyarakat Desa Bentung, Dinas Kebudayaan dan Pariwisata serta BAPPEDA Kabupaten Kepulauan Sangihe.

\section{DAFTAR PUSTAKA}

Bengen, D.G. 2001. Sinopsis Ekosistem dan Sumber Daya Alam Pesisir. Pusat Kelautan Institut Pertanian Bogor.

Creswell, J. W. 2010. Research design: pendekatan kualitatif, kuantitatif, dan mixed. PT Pustaka Pelajar. Yogyakarta.

Dahuri, R., Rais, Y., Putra, S.G., Sitepu, M.J. 2001. Pengelolaan Sumber daya Wilayah Pesisir dan
Lautan Secara Terpadu. PT. Pradnya Paramita. Jakarta.

David, F. 2009. Strategic Management: Manajemen Strategis Konsep. Salemba Empat. Jakarta.

Kertopati, L. 2016. Mengarunggi Tradisi Maluku dengan Manggurebe Arumbare. CNN Indonesia: https://m.cnnindonesia.com/hiburan/mengarungi-tradisi-maluku-dengan-manggurabe-arumbae/ (Diakses: 22 September 2017).

Labesi. 2017. Distant Voices, Dinas Pariwisata Kabupaten Kepulauan Sangihe. Sangihe. 4 Menit.

Masyhudzulhak, D. 2011. Pengelolaan Sumber Daya Wilayah Pesisir Dalam Perspektif Otonomi Daerah (Tinjauan Kota Bengkulu dan Kabupaten Bengkulu Selatan. Proceeding Book Simposium Nasional IImu Administrasi Negara Untuk Indonesia. 331-339

Muttaqin, M.F., Anggoro, S., Purwanti, F. 2015. Strategi Pengembangan Wisata Pesisir di Kelurahan Muarareja Kota Tegal. Management of Aquatic Resources Journal. Vol 4, No. 4, hlm 136-145.

Nawawi, H. 2005. Manajemen Strategik Organisasi Non Profit Bidang Pemerintahan. Gadjah Mada Press. Yogyakarta.

Nugroho, I. 2006. Pengembangan Pariwisata pesisir dalam Pembangunan Daerah.

Paturusi, S.A. 2001. Perencanaan Tata Ruang Kawasan Pariwisata, Materikuliah Perencanaan Kawasan Pariwisata Program Magister (S2) Kajian Pariwisata, Program Pasca Sarjana Universitas Udayana Denpasar.

Samsuridjal dan Kaelany. 1997. Peluang di bidang pariwisata. Mutiara Sumber Widya. Jakarta.

Siagian, S. P. 2011. Manajemen Strategik. PT Bumi Aksara. Jakarta.

Smith, S.L.J. 1989. Tourism Analysis, a Handbook. Longman Scientific \& Technical.

Soebagyo. 2012. Strategi Pengembangan Pariwisata di Indonesia. Jurnal Liquidity. Vol 1, No. 2, hlm 153-158.

Suwantoro, G. 2004. Dasar-Dasar Pariwisata. Andi. Yogyakarta. $67 \mathrm{hlm}$.

World Tourism Organization. 1980. The World Tourism Conference held in Manila (Philippines) adopts the Manila Declaration on World Tourism.

Yoeti, O.A. 1996. Pengantar Ilmu Pariwisata. Angkasa. Bandung. hlm 178. 


\section{Peraturan Perundangan:}

Undang-Undang No. 32 tentang Pemerintahan Daerah Pasal 18 ayat 4 .

Undang-undang Republik Indonesia Nomor 10 Tahun 2009 tentang Kepariwisataan. Bumi Aksara. Jakarta. 